\title{
Interpretation of Family Members' Involvement in Religious Groups
}

\section{Kurniati Abidin}

Department of Islamic Communication and Broadcasting, Faculty of Usuluddin and Dawah, Institut Agama Islam Negeri Bone, 92733, Bone, South Sulawesi Province, Indonesia Corresponding Author: kurniatiarifabidin@gmail.com

\begin{abstract}
ARTICLE INFO
Publication Info:

Research Article

How to cite:

Abidin, K. (2020). Interpretation of Family Members' Involvement in Religious Groups. Society, 8(2), 695-706.
\end{abstract}

DOI: $10.33019 /$ society.v8i2.178

Copyright (C) 2020. Owned by Author(s), published by Society

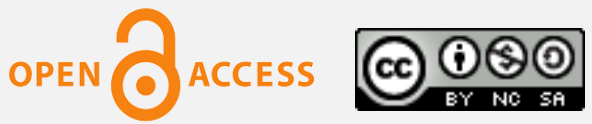

This is an open-access article.

\section{License: Attribution- \\ NonCommercial-ShareAlike (CC BY-NC-SA)}

Received: May 7, 2020;

Accepted: October 15, 2020;

Published: December 30, 2020;

\begin{abstract}
Family reactions and assessments of all family members towards family members belonging to specific religious groups still occur. This interpretation can trigger disharmony in the family and is an interesting social phenomenon to research. This research uses a qualitative research method. This research assumes that empirical realities occur in a socio-cultural context that is interrelated with one another. This research aims to describe family reactions, family social relationships, and family assessments on their family members' involvement in specific religious groups. The informants were selected using a purposive sampling technique by taking three people from each religious group (Jamaah Tabligh, Wahdah Islamiyah, and Lembaga Dakwah Islam Indonesia known as LDII). Data were collected using in-depth interviews, observation, and documentation. The data analysis used in this research is descriptive qualitative. The results showed that family social relations on family members' involvement in certain religious groups tended to get the same reaction based on their interpretation. Contravention interpretation from dominant family on family members belonging to specific religious groups still occurs compared with accommodative relationships. Meanwhile, family assessments on their family members' involvement in certain religious groups are generally negative.
\end{abstract}

Copyright (C 2020. Owned by Author(s), published by Society. This is an open-access article under the CC-BY-NC-SA license. 


\section{Introduction}

Religion has a significant role in creating values in the family. Religious values have been internalized for a long time in the family. The internalization of religion that lasts a lifetime of course influences how a person interacts with one another. The social interaction in a family dominated by religious values is undoubtedly different from a family whose social interaction pattern is based on secular values.

In sociology, religion's functions in two-dimensional social interactions are strengthening social cohesion and weakening social cohesion. Religion can function as destructive if religion becomes the catalyst for social discohesion. However, religion can function as constructive if religion reinforces social solidarity. This factor applies to every act of collectivity, including the family. Religion is the family's foundation because it contains values directed by primary socialization to maintain stability and harmony. However, on the other hand, the secondary socialization process can cause a clash of values when there are differences in principles and interpretations between the family members. According to Berger's conception, socialization always remains asymmetries (Berger \& Thomas, 1996, as cited in Bawono et al., 2017). What is instilled by family, instilled or internalized in an individual due to the socialization process, is not always aligned and straight with behavior. What is obtained in the family, obtained from secondary socialization such as school, and the environment is not a continuum, but it is a fragment that is often separated.

As the majority religion in Indonesia, Islam development has led to escalating various religious groups. Sociologically, according to Asror (2010), Islam is a socio-cultural phenomenon spread worldwide. Islam experiences dynamics that then give its color to society's characters worldwide. This socio-cultural phenomenon has led to various religious groups.

The family is the smallest social group in which family members have different statuses and roles. The role of the family is vital for the development of generations. Religion as a value system that is upheld by society also influences the family. Of course, the constructive function of religion should manifest itself in the family. However, in some cases, religion is the cause of the family breaks. Research by Calvina \& Yusuf (2012) showed that the primary source of conflict most often experienced originates from the family, especially parents. The two respondents' parents in this research contradicted their child's choice of religion, resulting in a conflict. The responses that appear can be different where the first respondent will remain on choice while the second respondent accepts the parents' decision.

The various phenomena above indicate that, in reality, religion can generate disharmony in the family. It is especially so when a family member belongs to a specific religious group that differs from most of the family's religious groups. It can potentially trigger disharmony in the family. This research will focus on how the family reacts, family social relations, and family assessments of their family members' involvement in relatively new religious groups.

\section{Literature Review}

The family is the first place for internalization to shape human knowledge and behavior. A family is a place for the socialization of values that live in society, including religion. Religious values are instilled from an early age. This research's theoretical framework concerns the relationship between religion and family life, especially the double-edged religion function, namely constructive and destructive functions. The sociological analysis knife used to see the relationship between religion and family is Symbolic Interactionism Theory, which is a development of Max Weber's interpretive sociological thinking about how humans act based on their meaning of the social world. 


\subsection{Family and Religion in a Sociological Review}

Family is the smallest collectivist but has a significant role in shaping the human personality. Mansyur (1977), as cited in Rustina (2014, p. 290), stated that family is the essential primary community in a society, which has proximity between its members. First social life learning is in the family. Purba (2004, p. 120) stated that the formation of human personality exists in family life. The family's function as a medium of enculturation that strengthened by normative rules governing relationships between individuals. Therefore, individuals obtain the process of enculturation firstly in the family.

Social interaction within the family will create social interaction dynamics that establish associative social relationships and dissociative social relationships between members. Dynamic social relationships in the family can lead to associative social relationship patterns, but it does not rule out dissociative social relationship patterns. Associative relationships between members of the family will create harmony because there are understanding and cooperation in it. Meanwhile, dissociative relationships cause conflict in the family.

Goldthorpe (1992, p. 264) stated that families have various forms, namely:

1) Nuclear Family, a group consisting of parents and their children, has not separated themselves, even though they are married and still live under one roof. The nuclear families are found in many communities in Sabang Hamlet, Bontobahari Village, Bontoa Maros SubDistrict. Meanwhile, the Conjugal Family is more autonomous and has no dependence on other family units, so that there is no strict supervision from other relatives.

2) Extended Family. Including the nuclear family plus other families who have a close and continually maintained relationship, live for several generations under one roof.

3) Stam Family. This family relies on the concentration of wealth inheritance, which the oldest child manages. So it only focuses on the oldest child and is responsible for other siblings, both male and female (until he/she is married).

4) Joint Family. Patriarchal families who prioritize the role of sons from birth already have the right to inherit the extended family from the father's side.

5) Family of Procreation and Family of Orientation. New families that are still regulated by the original family (Orientation) either from the parents-in-law or from the parents themselves, especially from young couples or new households who still live with the parents/parentsin-law.

The wider the membership of a family, the more complex the social dynamics that occur in it. The complexity of social relations in the family begins with the socialization of values that family members consider true. Actions of social interaction between members create social processes that children do during their growing up years. Socialization plays a huge role in the family. Aeri \& Verma (2004) reveal the importance of socialization in the house as a primary socialization space. Socialization is the process of interacting with other people. Children begin the process of social development from an early age. They learn to interact through play and imitate people's social actions in their home environment that are important to them.

Family members react with each other by paying attention to the social actions of each family member. Children themselves undergo a learning process by playing and imitating every social action in their home environment that is considered necessary. It is in the family that the transformation of humans from biological to sociological creatures occurs. Rustina (2014) stated that the family is a social institution that shapes children's behavior by using emotional bonds. 
Peter L. Berger, as cited in Riyanto (2009), stated that the organizational structuring method is a process of externalization and objectification. In the externalization process, initially, a group of people performs several activities. If the activity is deemed suitable and manages to solve their problems together at that time, then the activity will be repeated. After an activity experiences consistent repetition, logical human awareness determines that facts occur because rules oversee it. This is the objective stage after going through a series of processes.

Families need norms to regulate family members from values that can damage family members. It is at this point that religion plays a strategic function. The function of religion in maintaining social systems according to Structural Functionalism Theory is a function of latency. This function plays a role in maintaining the family's social system in order to survive.

Sociologically, religion itself is considered a social reality that has five elements, which according to Rakhmat (2003, p. 43), consist of:

1) The Ieological Dimension, a dimension that contains the basics of belief in God and Messengers, belief in divine purposes in human creation, and beliefs relating to the best way to carry out divine purposes.

2) The Ritualistic Dimension, the dimension related to specific behavior defined by religion, for example, rituals of worship.

3) The Experimental Dimension, a dimension related to religious feelings experienced by adherents (religious experience), for example, in prayer.

4) The Intellectual dimension, this dimension relates to many information known to these adherents.

5) The Consequential Dimension, this dimension is related to the consequences of religious teachings in general behavior.

In the fifth element, namely the consequential dimension, religion's role can be traced, especially in the family. Each element is a unity that makes religion function well in the family. Thomas F. O'Dea, as cited in Saebani (2007, p. 17), provides an overview of the function of religion, as follows:

1) Religion bases its considerations on something beyond the reach of humans by involving destiny and welfare, providing positive inspiration for its adherents, as well as solace and reconciliation. Religion provides support and encouragement when humans are under pressure and vulnerability, disappointment, and dissatisfaction. Religion is also a need for reconciliation with society if it is far from its goals and norms. Religion provides an effective emotional means that can help deal with every element of the condition that occurs in humans.

2) Religion offers a transcendental relationship through worship at religious ritual ceremonies. Hence, religion can provide the premise for a sense of security and self-confidence in relieving the stresses of living today and in the future. Religion helps reduce the stresses of life that can cause stress. Religion provides advice and guidelines for understanding social problems from various perspectives.

3) Religion gives and sanctifies established norms and values of society, maintaining group goals domination over individual desires. In this way, religion strengthens the legitimacy of the division of functions, facilities, and rewards characteristic of a society.

4) Religion carries out a critical function of various values in the normative past. The function of religious treatises can conflict with existing values. The religious treatise is seen as a threat to existing and established social norms. There is a function of deconstruction in 
religion, then reconstructing it with a new value system even though it has gone through a long socialization journey.

5) Religion performs the function of identity through the values of religious teachings that are believed to be sacred by its adherents. Individually, religion develops important aspects of self-understanding and self-limitation. Religion gives individuals a sense of identity in the past that is identified in the future. This is a historical record that will be read in a future time outside the world.

6) Religion performs the function of maturity. Every human age is calculated between reward and life sanctions. Religious teachings guide humans to mature the function of age towards true happiness in life. One meaningful way to form self-identity is to believe in transcendental and immanent religions. According to their religion, emotional ties between the same adherents in religion are the most valuable identities in providing symbols of togetherness and interests in achieving life goals.

The functions of criticism, identity, and maturity are functions that have sociological relevance. Changes in family religious understanding are strongly influenced by the family's response to their environment. Religion has become the object of sociological studies, which has resulted in the study of the sociology of religion. Furseth \& Repstad (2006, p. 17) stated that the sociology of religion is a subject of religious studies in its social context but applies the same theories and methods used to study economics, politics, and other social phenomena. In general, sociologists of religion are interested in religion's influence on society and its influence on religious life. In this study, the relationship between religion and culture shows family members' meaning towards family members' involvement in religious groups. Family members, in this case, the informants, then internalize the values adapted from the religious groups they follow. This process then led to a variety of intersubjective interpretations that differed between families and religious group participants.

\subsection{Symbolic Interactionism Theory}

Symbolic Interactionism Theory is a variant of sociological theory that has particularities.

Tabel 1. Comparison of Theoretical Perspective in Sociology

\begin{tabular}{|c|c|c|c|}
\hline Point of View & Functionalist & Conflict & Interactionism \\
\hline Society & $\begin{array}{l}\text { Stable, constant and } \\
\text { integrated }\end{array}$ & $\begin{array}{c}\text { Full of competition } \\
\text { and conflict }\end{array}$ & $\begin{array}{l}\text { Actively influence each } \\
\text { other in daily life }\end{array}$ \\
\hline $\begin{array}{c}\text { Analysis } \\
\text { Level }\end{array}$ & Macro & Macro & $\begin{array}{l}\text { Micro, analysis is an } \\
\text { attempt to understand a } \\
\text { broader phenomenon }\end{array}$ \\
\hline Social Change & Predictable & $\begin{array}{c}\text { Changes will } \\
\text { continue to occur } \\
\text { and have a positive } \\
\text { impact }\end{array}$ & $\begin{array}{l}\text { Change is a logical } \\
\text { consequence of social } \\
\text { status and communication } \\
\text { with others }\end{array}$ \\
\hline Social Order & $\begin{array}{l}\text { Through cooperation } \\
\text { and consensus }\end{array}$ & $\begin{array}{l}\text { Through strength } \\
\text { and violence }\end{array}$ & $\begin{array}{l}\text { Through mutual } \\
\text { understanding of daily } \\
\text { behavior }\end{array}$ \\
\hline
\end{tabular}

Copyright () 2020. Owned by Author(s), published by Society. This is an open-access article under the CC-BY-NC-SA license. 


\begin{tabular}{cccc}
\hline Point of View & Functionalist & Conflict & Interactionism \\
\hline \multirow{2}{*}{ Protagonist } & Emile Durkheim, & Karl Marx, & George H. Mead, \\
& Talcott Parson, & C. Wright Mills & Charles H. Cooley, \\
& Robert K. Merton & Erving Goffman \\
\hline
\end{tabular}

Source: Ritzer (2007)

This research uses interactionism theory as an analysis tool to examine family reactions and family social relationships and family assessments of their family members' involvement in certain religious groups. Symbolic interaction theory cannot be separated from the social actions of actors. The social action of the individual is fundamental to understanding Symbolic Interactionism Theory.

Symbolic interactionism theory emphasizes the individual's ability to give meaning to the symbolic context that surrounds them. The meaning process indicates the way a person defines self-assessment. Haryanto (2012) stated that the central point of symbolic interactionism theory is to see how members of society produce and reproduce their knowledge system through social interactions that they intertwine in everyday life through symbols. Individuals thus have the natural and cultural ability to interpret the meaning of various objects around them during social interactions.

Social interactionism theory emphasizes a micro approach where research focuses on social action directed at others mediated by symbolic structures. These symbols get a meaningful process that determines a person's thoughts, attitudes, and behavior.

\section{Research Methodology}

This research is field research. This research uses a qualitative research method. According to Ali (2002), qualitative research uses a natural paradigm, meaning that this research assumes that empirical realities occur in a socio-cultural context interrelated. This research's nature is descriptive, which describes the data as it is when the research was conducted used a sociological approach. The sociological approach is used to observe the social relationship between family members who join a specific religious group and their family environment. This research was conducted in Watampone, Bone, South Sulawesi Province, Indonesia, considering many relatively new religious groups in this city. The instruments used in this research were interviews, observation, and documentation. In qualitative research, the main instrument that plays a role in the research process is the researcher.

In this research, the researcher acts as a non-participant observant who directly interviews the sources. The data sources were members of the religious groups that emerged in Watampone, namely Jamaah Tabligh, Wahdah Islamiyah, and Lembaga Dakwah Islam Indonesia (LDII). The informants were selected using a purposive sampling technique by taking three people from each religious group. The data analysis used in this research is descriptive qualitative. Given its qualitative form, the analysis is carried out when data collection or analysis is intended to determine the focus of attention during data collection. In this regard, it begins with first examining all available data from various sources of in-depth interviews and observations that have been written in field notes. Because there are many data, after reading, studying, and analyzing, data reduction is carried out by making an abstraction, namely an effort to summarize the core, process, and statements. The next step is to organize the data into units. The units are then categorized. Categories are performed when coding. The final stage of this data analysis is to check the validity of the data. After completing this stage, begin the data

Copyright (C 2020. Owned by Author(s), published by Society. This is an open-access article under the CC-BY-NC-SA license. 
interpretation stage in processing interim results. In short, the data analysis step is to process the data into several units, categorize, and interpret the data.

\section{Results and Discussion}

\subsection{Family Reactions and Family Social Relations to the Involvement of Family Members in Religious Groups}

The involvement of family members in a group of religious organizations that is relatively new produces reactions from other family members. The reactions that occur, of course, affect social relationships in the family. Family reactions are a natural part because family members' religious beliefs are considered foreign to the whole family.

In the sociology of religion, new religious groups are considered against the religious faith prevailing in the society. The emergence of new religious groups is part of the phenomenon of the contestation between religious beliefs. The emergence of alternative streams is a symptom of social change occurring in society due to new understandings.

The emergence of new religious groups is a necessary social process. Social processes with nuances of value change, including religion, will generate various responses. Family members who are considered deviant certainly provoke reactions and affects social relations in the family.

The reactions given by the family include, among others, the wife is angry and rebellious because the husband leaves work, the parents are angry, and they do not support dawah activities. There is a conflict between parents and children because of differences in opinion about the family's habits. Generally, families do not support religious activities that are participated in by their family members, and they generally experience conflicts with their families after joining the religious group.

This research shows that all informants experience social change mechanisms from an idealistic perspective. The informant experienced changes in the new religious knowledge order that he had acquired through his religious activities. So far, the religious knowledge that they have obtained from their family is different after studying with the religious group they chose. These changes bring internal dynamics of the family with different intensities of acceptance. When viewed from the family acceptance, informants generally experience contravention when joining a new religious group. The following is a table of informant interactions in the family:

Tabel 2. Informant's social interaction with family

\begin{tabular}{ccc}
\hline Informant & Religious Group & Social Relations in the Family \\
\hline Cb, HS, IQ & Jamaah Tabligh & Contravention \\
HMR, KK & Wahdah Islamiyah & Contravention \\
MUL, YUS & LDII & Contravention \\
NN & Wahdah Islamiyah & Accommodative \\
UN & LDII & Accommodative \\
\hline
\end{tabular}

Source: Field data processed (2020)

The table above shows that informants who actualize themselves in all religious groups tend to get the same reaction even though reactions in opposition from their families are still dominant compared to accommodative relationships. The internal dynamics of this study tend to show a dissociative relationship in the form of contravention. Contravention is a social form process between competition and conflict dispute. Contravention is mainly characterized by

Copyright (C 2020. Owned by Author(s), published by Society. This is an open-access article under the CC-BY-NC-SA license. 
symptoms of uncertainty about oneself or plans and feelings of hidden dislike, hatred, or doubts about one's personality (Soekanto, 2007, p. 65).

Facts in the form of interviews show the dynamics of social interactions carried out by informants. Bruce \& Yearley (2006, p. 156) stated that social interaction emphasizes that when people interact, they do so in light of the social expectations and background assumptions they bring to that meeting. People make assumptions about the motivations, experiences, intentions, and abilities of others. Social interaction emphasizes the way humans interact in which some basic expectations and assumptions are conveyed to others. The informants have expectations that their teachings can be understood and followed. All informants assumed that there was something wrong with the Islamic teaching implementation in their family.

They present uniqueness in religion that is different from their environment, for example, using a large headscarf and veil. There is an attempt to show the difference in symbols. Of course, symbolic differences are shown to confirm a new identity in religion. The expected expectation is, of course, the other person's reaction. The perspective of Symbolic Interactionism Theory stated by Ritzer \& Smart (2011, p. 430) explained this phenomenon by viewing humans as unique creatures due to their ability to use symbols to manage their interactions with other humans. Humans also have active self-awareness and reflection to shape their behavior and act purposively in various situations, so they need a method to explain each action's meaning.

Social interaction theory illustrates that each informant can utilize the symbols he uses in interacting. Changes in all informants' religious beliefs show a reflective stage of the general diversity that exists in society. The informants' aim with the change in beliefs and symbols attached to their new teachings was to invite others to stay away from old beliefs that were considered wrong. The informants gave meaning to some of the community's religious practices that are contrary to Islam. They interpret the mixture of culture and Islam as wrong.

The entire belief structure of the informants shows the process of interpreting the religious symbols they observe. The informant's family also made an effort to interpret the informant's new religious teachings. The two parties, especially those who have a dissociative pattern of interaction, have different meanings. The family gives a negative meaning and even tends to be stigmatic, for example, the stigma of a large headscarf and veil as heretical and terrorist teachings.

\subsection{Family Assessments of Family Members' Religious Beliefs}

Family members involved in a new religious group are likely to receive an assessment from their family members. The family also gives meaning to informants' model of religious behavior. The data show variations in the family assessment of several informants. Some family members think that the informants' religious group teachings are contrary to what they have understood. The contradiction from within the family members arises because of the distinction between primary religious socialization and secondary socialization. Several Islamic religious faith principles are interpreted between parties in the family and the values brought from a religious group adherent by family members.

Some family negation also arises because involvement in this religious group causes them to leave their jobs. This rational choice regarding religion is rejected by rationality in the family. Stigma from outside the family also affects family interpretations, such as using the veil, representing radical Islamic extremists, and the names of religious groups that are considered to deviate from Islamic values.

In principle, there are social dynamics between informants and families. Sociologically, religious behavior is the social behavior of a person who is faced with social reality. Andersen \&

Copyright (C 2020. Owned by Author(s), published by Society. This is an open-access article under the CC-BY-NC-SA license. https://doi.org/10.33019/society.v8i2.178

702 
Taylor (2011) stated that sociology studies the presence of social realities that shape human behavior, where every human behavior or action is always tied to the surrounding community's context.

This research shows that their social context influences informants' behavior. The social context in question is the institutions and culture that are part of their life, which broadly determine the informants' behavior and thoughts.

At the religious experiences of informants, especially those who get opposition, in that case, it can be seen that in Berger \& Luckmann's perspective, humans are not merely a reflection of their structure. There is a dialectic when informants are faced with their social structure. This dialectic produces social dynamics in which there is opposition to the religious traditions adhered to by society. The informants creatively show their existence and are directly face with their social reality.

They were internalizing Islamic values that they obtained before the informant changed shows a dynamic where the internalizing of old Islamic teaching values is dialectic with the internalizing of new Islamic teaching values. The informants addressed that new Islamic teaching values are more suitable for religious teaching values. This attitude is then followed by an externalization process in which the informants spread new Islamic ideas and values to their families and communities. This process is known as three processes, namely internalization, objectivation, and externalization. Peter L. Berger, as cited in Riyanto (2009) through the picture below:

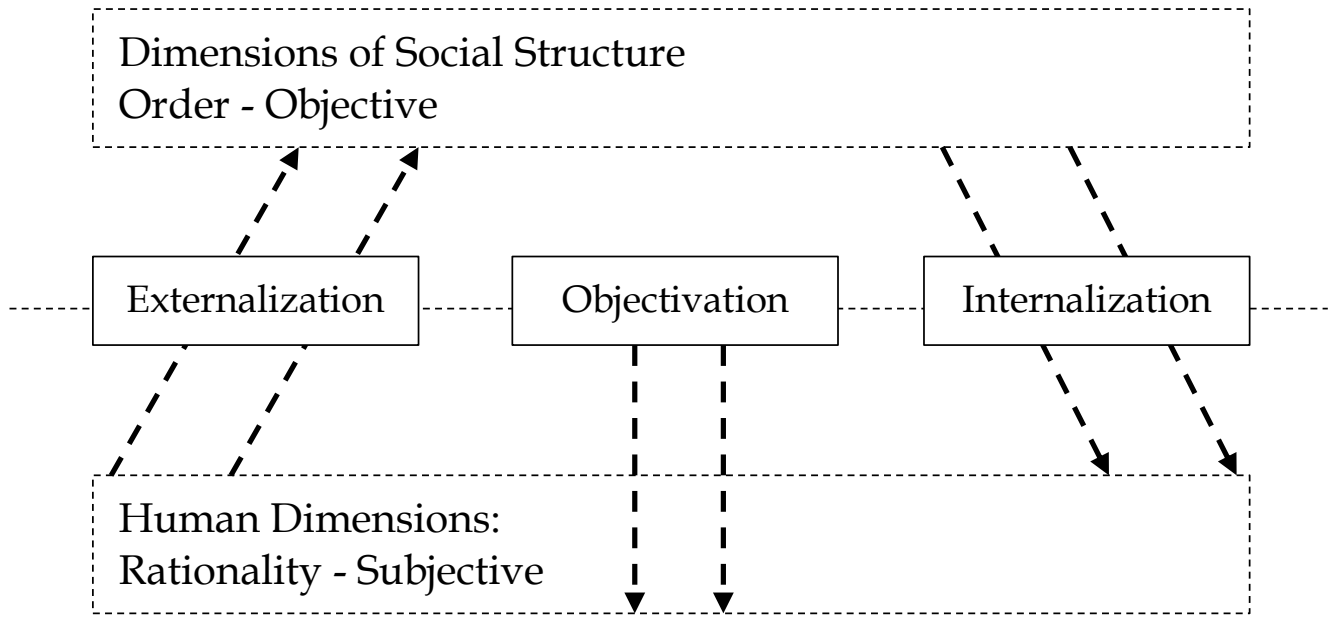

Figure 1. Internalization, Objectivation, and Externalization Processes

Source: Peter L. Berger, as cited in Riyanto (2009)

Dialectics between humans and society occurs through three processes: externalization and objectification, while the third is internalization. Through internalization, humans become products rather than (formed by) society. Internalization functions to transmit institutions as independent realities, especially to new members of society. These institutions can be maintained from time to time, even though members of society who conceptualize social institutions also experience internalization. These three processes become the dialectical cycle in the relationship between humans and society. Humans shape society, but then humans are formed by society.

Internalization occurs through the socialization mechanism. In this case, Berger follows Mead's Theory in Symbolic Interactionism. Humans live in institutions that regulate their position and other ego positions. Human behavior and actions in the middle of a social context 
show their role. Therefore, human behavior in the middle of its social context is always symbolic, referring to a message or meaning. Humans who do not know the institution's rules or regulations can learn them through other symbolic ego actions or behaviors.

Through internalization, the objective social reality outside humans (as an institution) becomes an objective reality within humans (as part of consciousness). Through internalization, social reality becomes something that is taken for granted by humans. Society as a social reality is taken for granted as a fact that is external to humans. However, according to Berger, socialization is never perfect. Institutions passed to new members can always be questioned because new members may be aware that their circumstances are different and do not have the collective consciousness of previous generations. Therefore, individuals can question this social reality. An institution must be based on legitimacy to maintain it. Legitimacy puts cognitive justifications or explanations based on logical evidence of an institution's relevance when the institution is deemed insufficient or irrelevant in answering the problems that arise. In symbolic interaction theory, the informant is seen as an active figure in interpreting and having a selfconcept.

Informants demonstrate their ability to see themselves. They are aware of their new identity and show it to the family. The informants were also aware of reactions in the form of family assessments. The family gives the assessments to the informants included:

1) the wife judged that the actions taken by her husband to join a religious group were wrong

2) the wife judged that without Khuruj fi Sabilillah (method of dawah which is carried out in different places), the husband could gain knowledge

3) the parents considered leaving the job obtained was wrong

4) the parents judged that leaving their long tradition of being wrong

5) the scorn from neighbors made parents judge the informants' actions as wrong

From all family assessments of informants, it is generally seen that most informants receive negative ratings within the family at the beginning of their transformation. Then at the next stage, all the informants developed some feeling in reaction to the family reaction. Their feelings are manifested in actions in the form of greater solidity towards their new teachings and meaning that if the family does not want to follow them, it is a sign that the family has not received guidance. There is a symbolic clash through religious values brought from religious groups with different interpretations of Islamic values that families understand.

The friction between family interpretations and members involved in religious groups is part of the construction process or self-concept formation of how individuals in these religious groups attempt to negotiate their self-identity, internalizing from primary and secondary socialization.

\section{Conclusion}

The family's interpretation of the new religious teaching model was initially in the form of a contravention, even though some informants did not get a strong reaction. The social dynamics between informants and families are none other than due to social interactions mediated by symbols reflected in how the informants reflect on their identity, for example, through Muslim clothing that is different from society. Second, the more non-compromising the informant's social interactions with the family, the less opportunity they have to socialize their new teachings. The more the socialization of the teachings is less acceptable, the more the process of assimilation with the family is hampered so that the interaction pattern tends to be dissociative.

Copyright (C 2020. Owned by Author(s), published by Society. This is an open-access article under the CC-BY-NC-SA license. https://doi.org/10.33019/society.v8i2.178

704 
The social dynamics between informants and their families in the sociology of religion reflects the consequential dimensions of religion. The consequential dimension is interpreted as the behavior of religious communities in the public space. The research results show that reflections on diversity in the public sphere will cause reactions in social relations patterns, whether they are associative or dissociative. If the religious reflection is considered too vulgar in exposing the family's diversity, then that religious reflection will get opposition. The results of social dynamics are highly dependent on the interaction skills built by a person. The more their social interactions show non-compromising behavior, the more difficult it is to socialize their new teachings to the family. Obstructed socialization becomes an indicator of the failed assimilation process.

\section{Acknowledgment}

The author is grateful to express gratitude to those who have had the pleasure to cooperate during this study.

\section{Declaration of Conflicting Interests}

The author has declared no potential conflicts of interest concerning the study, authorship, and/or publication of this article.

\section{References}

Aeri, P., \& Verma, S. K. (2004). Child's Socialization Through Play Among 2-4 Years Old Children. The Anthropologist, https:/ / doi.org/10.1080/09720073.2004.11890868

Ali, M. S. (2002). Metode Penelitian Agama: Pendekatan Teori dan Praktek. Jakarta, Indonesia: PT Raja Grafindo Persada.

Andersen, M. L., \& Taylor, H. F. (2011). Sociology: The Essential. Wadsworth, United States: Cengage Learning.

Asror, A. (2010). Reproduksi Islam dalam Tradisi Keberagamaan Populer di Lingkungan Masyarakat Santri Jawa. Annual Conference on Islamic Studies 2010. Banjarmasin, Indonesia: Sekretariat Badan Litbang dan Diklat Badan Litbang dan Diklat Kementerian Agama Republik Indonesia.

Bawono, H., Wilujeng, P. R., \& Ikramatoun, S. (2017). Menjadi Misionaris: Sosialisasi-Komitmen Agama Elder Dan Sister Mormon-Gereja Yesus Kristus. Dialektika Masyarakat: Jurnal Sosiologi, 1(1), 87-102. Retrieved from https://jurnal.uns.ac.id/dmjs/article/view/21696

Bruce, S., \& Yearley, S. (2006). The SAGE Dictionary of Sociology. London, United Kingdom: SAGE Publications.

Calvina, C., \& Yusuf, E. A. (2015). Konflik pemilihan agama pada remaja dari perkawinan beda agama. Predicara, 2(1). Retrieved from https://jurnal.usu.ac.id/index.php/predicara/article/view/3868

Furseth, I., \& Repstad, R. (2016). An Introduction to the Sociology of Religion: Classical and Contemporary Perspectives (1st ed.). London, United Kingdom: Routledge.

Goldthorpe, J. E. (1992). Sosiologi Dunia Ketiga: Kesenjangan dan Pembangunan. Jakarta, Indonesia: Gramedia Pustaka Utama.

Haryanto, S. (2012). Spektrum Teori Sosial: Dari Klasik Hingga Postmodern. Yogyakarta, Indonesia: Ar-Ruzz Media. 
Purba, J. (2004). Peran Keluarga Batih dalam Pembentukan Kepribadian dan Identitas Etnik. Pemberdayaan Komunitas, 3(3), 119-122. Retrieved from http://repository.usu.ac.id/handle/123456789/15658

Rakhmat, J. (2003). Rekayasa Sosial: Reformasi, Revolusi, atau Manusia Besar. Bandung, Indonesia: PT Remaja Rosdakarya.

Ritzer, G. (2007). Sosiologi Ilmu Pengetahuan Berparadigma Ganda. Jakarta, Indonesia: PT Raja Grafindo Persada.

Ritzer, G., \& Smart, B. (2011). Handbook Teori Sosial. Bandung, Indonesia: Nusa Media.

Riyanto, G. (2009). Peter L. Berger: Perspektif Metateori Pemikiran. Jakarta, Indonesia: LP3ES.

Rustina, R. (2014). Keluarga dalam Kajian Sosiologi. Musawa: Journal for Gender Studies, 6(2), 287322. Retrieved from http://jurnal.iainpalu.ac.id/index.php/musawa/article/view/288

Saebani, B. A. (2007). Sosiologi Agama: Kajian tentang Perilaku Institusional dalam Beragama Anggota Persis dan Nahdatul Ulama. Bandung, Indonesia: Refika Aditama.

Soekanto, S. (2007). Sosiologi Suatu Pengantar. Jakarta, Indonesia: Rajawali Press.

\begin{abstract}
About the Author
Kurniati Abidin, obtained her Doctoral degree in Sociology from Universitas Negeri Makassar, Indonesia, in 2016. The author is an Associate Professor at the Department of Islamic Communication and Broadcasting, Faculty of Usuluddin and Dawah, Institut Agama Islam Negeri Bone, Indonesia.

E-Mail: kurniatiarifabidin@gmail.com
\end{abstract}

